Zabytkoznawstwo i Konserwatorstwo XLIII, Toruń 2012

Bartosz Anusiak, Robert Rogal

Instytut Zabytkoznawstwa i Konserwatorstwa, Wydział Sztuk Pięknych, UMK w Toruniu

\title{
Możliwości zastosowania technologii wirtualnej rzeczywistości w dokumentacji i projektowaniu konserwatorskim*
}

W roku 1796 malarz z Edynburga - Robert Barker wynalazł i opatentował metodę przedstawiania na płótnie otaczającego krajobrazu. Na poziomym pasie płótna namalował wówczas panoramę miasta, przekładając na płaszczyznę, widok widziany wokół siebie $-360^{\circ}$. Odbiorca, oglądając obraz od jednego końca do drugiego, doświadczał wrażenia obracania się wokół własnej osi, podczas gdy w rzeczywistości obraz pozostawał statyczny ${ }^{1}$. [FOT. 1]

W XIX wieku dużą popularność uzyskały panoramy prezentowane w specjalnie zaprojektowanych do tego celu budynkach. Początkowo przed-

* Niniejszy artykuł jest fragmentem pracy magisterskiej obronionej w 2007 roku w Zakładzie Konserwacji Malarstwa Sztalugowego, Ściennego i Rzeźby Polichromowanej, na Wydziale Sztuk Pięknych UMK w Toruniu, napisanej pod kierunkiem dr. Roberta Rogala, w ramach seminarium pani prof. dr Bogumily Rouby. Ponad rok po obronie pracy magisterskiej w Biuletynie Informacyjnym Konserwatorów Dzieł Sztuki ukazał się artykuł opisujący w analogiczny sposób założenia wcześniejszej pracy magisterskiej: Karol Kwiatek, Paweł Boliński Panoramiczne wizualizacje zabytków, Biuletyn Informacyjny Konserwatorów Dzieł Sztuki, vol. 19, nr 1-4 (72-75) 2008, s. 52-57

1 Virtual Edinburgh: 200 Years of image innovation, Material prepared for the Edinburgh Science Festival 1999. The Edinburgh Virtual Environment Center, University of Edinburgh, www.edvec.ed.ac.uk 
stawiały głównie widoki miast, w drugiej połowie wieku pojawiła się tematyka batalistyczna, historyczna i religijna. Były przejawem kultury masowej poprzedzającej pojawienie się sztuki filmowej.

Kwestię panoramicznego odwzorowania rzeczywistości odnajdujemy również w ścisłym połączeniu z fotografia. Jej rozwój łączy się z szeregiem patentów umożliwiających fotografowanie panoramiczne. Tego typu urządzenia produkowane są od ponad 160 lat. Różnią się między sobą konstrukcją i wielkością kąta widzenia - od $110^{\circ}$ do $360^{\circ}$. Pierwszy odnotowany przypadek pochodzi z Austrii, z 1843 roku. Joseph Puchberger, aptekarz z miasta Retz, w dagerotypie własnej konstrukcji zastosował specjalna ruchomą soczewkę, która umożliwiała wykonanie zdjęcia o kącie widzenia 150․ W 1857 roku, Michael Garella skonstruował w Anglii, pierwszy aparat umożliwiający fotografowanie $360^{\circ}$ pola widzenia. W XX wieku pojawiają się w pełni profesjonalne rozwiązania, wiodacych firm fotograficznych ${ }^{2}$. W 1904 roku, Kodak, opatentowal aparat tzw. „Circut camera” umożliwiający wykonanie $360^{\circ}$ panoramy na jednej kliszy. Aparat znalazł zastosowanie m.in. w fotografowaniu widoków miast i krajobrazów oraz dużych grup ludzi - wykorzystywano go szczególnie w zdjęciach szkolnych ${ }^{3}$. [FOT. 2]

Wart odnotowania jest fakt, że fotografia panoramiczna zawędrowała nawet w kosmos - 21 lipca 1969 roku Neil Armstrong, dowódca misji „Apollo 11”, jako pierwszy człowiek w historii stanął na Księżycu. Kolejne wyprawy misji Apollo przywożą na Ziemię fotografie panoramiczne przedstawiające powierzchnię „srebrnego globu”4.

Komputeryzacja umożliwiła ponowne wykorzystanie $360^{\circ}$ panoram złożonych z serii zdjęć wykonanych aparatem zamontowanym na obrotowym statywie. Co więcej, komputer umożliwił poszerzenie widoku panoramicznego, przekształcając klasyczną obrotową prezentację w pełny

2 Bill McBride, Panoramic Camera 1843-1994, www.cirkutpanorama.com/Timelin.html; polskie tłumaczenie tekstu znajduje się na stronie www.panoramy.art.pl/przeglad_historyczny.html . Artykuł zawiera szczegółowy opis kolejnych wynalazków w fotografii panoramicznej wraz z nazwiskami twórców i opisami technicznymi

3 Erly panoramic photographs, www.shortcourses.com/how/panoramic/panoramic.htm

4 Opis misji Apollo znajduje się na polskich stronach internetowej encyklopedii „,Wikipedia” pl.wikipedia.org/wiki/Program_Apollo . Panoramy księżycowe w technologii QTVR obejrzeć można pod adresem www.fullscreenqtvr.com/04extreme01_10.html 
sferyczny widok z możliwością interakcji, swobodnego obracania się we wszystkich kierunkach.

Wraz z ciagłym rozwojem techniki pojawiają się nowe metody, które mogą udoskonalić pracę konserwatora dzieł sztuki. Jedną z nich jest technologia wirtualnej rzeczywistości (VR z angielskiego virtual reality) tworzona m.in. na podstawie autorskich rozwiązań firmy Apple. Szereg zdjeć wykonanych $z$ obrotowego statywu, po złożeniu za pomoca programu komputerowego w całość, tworzy na monitorze komputera wirtualną przestrzeń, którą widz może oglądać mając wrażenie obecności w jej wnętrzu.

Technologia VR może więc znaleźć szczególne zastosowanie w dokumentacji i projektowaniu konserwatorskim. Inne, dostępne obecnie technologie odwzorowujące przestrzeń posiadaja w większości podstawowe ograniczenie uniemożliwiające szersze zastosowanie - bardzo wysokie koszty specjalistycznych urządzeń oraz ich znaczny stopień skomplikowania. Technologia wirtualnej rzeczywistości VR wykorzystująca dostępne narzędzia, jakimi są aparat cyfrowy i komputer, jest więc alternatywnym rozwiazzaniem.

Prezentacja składa się z rzędów fotografii, wykonanych przy pomocy aparatu zamontowanego na statywie. W trakcie fotografowania, aparat obracany jest wokół punktu nodalnego obiektywu ${ }^{5}$ - miejsca, w którym krzyżują się promienie światła odbite od obiektu. Zdjęcia po nałożeniu przy pomocy programów komputerowych na wnętrze sfery tworzą $360^{\circ}$ wirtualną interaktywną panoramę. Bez względu na to jaką użyjemy aplikację do montażu projektu, zasada działania pozostaje zawsze taka sama.

Do wykonania pełnej panoramy - tzw. kubicznej ( $\mathrm{z}$ ang. cubical panorama), dla stworzenia pełnej sfery, wymagana jest seria zdjęć w minimum trzech „liniach”6. Pierwsza, gdy kąt nachylenia aparatu odpowiada kątowi horyzontu, druga, gdy kąt nachylenia aparatu zawiera się między horyzontem a zenitem $\left(45^{\circ}\right)$ i trzecia, gdy kąt ten zawarty jest pomiędzy horyzon-

5 Punkt zazwyczaj nazywany skrótowo NPP, od angielskiego no paralax point, lub punktem „nodalnym” obiektywu, w rzeczywistości winien być określany terminem ściślej odpowiadającym faktycznemu stanowi - „źrenicą obiektywu”.

6 Sytuacja ta nie występuje w przypadku obiektywów szerokokątnych - typu „fish-eye”, gdzie do pełnej sfery wystarczy jeden poziom zdjęć + fotografię nadiru i zenitu. 
tem a nadirem, czyli $-45^{\circ}$ katowych. Dla zamknięcia sfery potrzeba nam jeszcze zdjęcia „zenitu” i „nadiru” (+90 i $\left.-90^{\circ}\right)$. [RYS.1]

Ilość zdjęć przypadająca na jedna ,linię” uzależniona jest od parametrów obiektywu jakim posługujemy się w trakcie pracy. Na załączonym powyżej przykładzie jest to dwanaście ujęć. Poszczególne fotografie muszą na siebie „zachodzić” - dzięki temu zastosowana przez nas aplikacja komputerowa będzie miała możliwość odpowiedniego dopasowania pojedynczych fragmentów w całość.

Stworzone tą metodą wirtualne wnętrze jest w pełni interaktywne - to użytkownik sam decyduje w jakie miejsce spojrzeć, w którą stronę się obrócić, jaki fragment przybliżyć. Widok z kilku punktów obiektu można połączyć w jeden pokaz - wirtualny „spacer”. Do przeglądania projektu potrzebna jest jedynie darmowa aplikacja Quick Time firmy Apple lub plugin do odczytywania plików w formacie flash ${ }^{7}$. [FOT. 3]

Rozbudowane możliwości jakie daje technologia VR oparta o panoramy sferyczne umożliwia wykorzystanie wirtualnej rzeczywistości w wizualizacji procesów konserwacji. Spośród najważniejszych, sprawdzonych zastosowań należy wymienić:

1. Dokumentowanie stanu zachowania obiektu. Na wirtualny model sklepienia, ścian kaplicy, fasady budynku możemy nanieść miejsca odspojeń, niewidoczne na zdjęciach detale, drobne ubytki, przemalowania, partie oryginału itd. Obiekt oglądać możemy jako całość, wraz z kontekstem, otoczeniem.

2. W ramach dokumentacji wykonywanie szczegółowych rysunków na bazie wykonanego projektu VR. Nanoszenie na wirtualny model informacji o stanie zachowania, miejscach wykonywanych zabiegów.

3. Pokazanie proponowanych rozwiązań estetycznych, co umożliwia pełne przewidzenia zmian, sprawdzenie czy dane rozwiązanie będzie właściwe bez konieczności ingerencji w zabytkowa materię. Możliwość wirtualnego pokazania wyników prac, przedyskutowania w szerszym gronie ważnych problemów dotyczących obiektu.

4. Rekonstrukcję poszczególnych faz chronologicznych obiektu. W sposób przystępny i czytelny mamy możliwość (na podstawie badań)

7 W praktyce, w miarę upływu czasu do wyświetlania panoram zaczęto w przeważającej części wykorzystywać flash’a. 
zobaczyć jak np. dana kaplica wyglądała w poszczególnych okresach historycznych. W wirtualnym świecie mogą w pełni współistnieć wszystkie fazy chronologiczne.

5. Dokumentowanie procesów konserwatorskich. Na wirtualny model możemy nanieść miejsca pobrania próbek, stratygrafię warstw, miejsca gdzie podklejano warstwy, usuwano przemalowania, stosowano poszczególne preparaty. Wydaje się to szczególnie pomocne w przypadku dużych wnętrz, gdzie wykonanie tradycyjnego rysunku i kalek jest czasochłonne i skomplikowane.

6. Wykorzystanie w badaniach, jako rozbudowa metod nieniszczących - m.in. metody „fałszywych kolorów”, podczerwieni, luminescencji wzbudzonej UV.

Technologia wirtualnej rzeczywistości łączy się bezpośrednio z potrzebą odpowiedniego zaprezentowania wyników pracy. Największymi jej zaletami są: 1. Możliwość prezentacji w dowolnym miejscu za pośrednictwem komputera stacjonarnego, przenośnego lub nawet telefonu komórkowego typu smartfon.

2. Do odtworzenia pliku wymagana jest jedynie instalacja darmowego pluginu Quick Time Player firmy Apple lub flash firmy Adobe.

3. Pliki z prezentacjami można umieszczać w pokazach programów Power Point, Open Office Viewer lub za pośrednictwem rozbudowanych aplikacji typu Director, Macromedia Flash, Swish.

4. Standardowy plik prezentacji panoramicznej ma rozmiar około 6-10 MB, nadaje się więc do przesyłania za pośrednictwem poczty elektronicznej. Niewielkie rozmiary plików umożliwiają więc umieszczanie ich na stronach internetowych.

5. Kilka panoram sferycznych składających się na wnętrze danego obiektu można prezentować za pośrednictwem witryn internetowych w formie wirtualnego spaceru.

Technologia wirtualnej rzeczywistości spełnia wszelkie wymagania do jej zastosowania w dokumentacji i projektowaniu konserwatorskim. Za jej adaptacją do potrzeb dokumentacji i projektowania konserwatorskiego przemawiają szerokie możliwości, dostępność technologii i łatwość jej zastosowania.

Wirtualne modele wnętrz lub ich elementy odzwierciedlają charakter przestrzenny obiektów dużo pełniej niż typowe zdjęcie, rysunek lub opis. 
Mogą być alternatywą lub uzupełnieniem dla tradycyjnych form dokumentacji. $\mathrm{Na}$ wirtualnym modelu możemy umieszczać informacje dotyczące technologii i techniki wykonania obiektu, stanu zachowania oraz obecności i zakresu występowania nawarstwień historycznych i ingerencji konserwatorskich. Wszelkie naniesione informacje moga występować w formie graficznej lub tekstowej. Wirtualne wnętrza mogą być również budowane $\mathrm{z}$ fotografii wykonanych $\mathrm{w}$ innych pasmach promieniowania.

Artykuł składający się z tekstu i nieruchomych fotografii nie pozwala na pełna prezentację możliwości multimedialnej technologii. Praktyczne przykłady zastosowania technologii wirtualnej rzeczywistości odnaleźć możemy pod adresami internetowymi

\section{Summary}

\section{The virtual reality application usage possibilities in conservatory do- cumentation and design}

The documentation and design are integrity actions in planning and execution of a conservatory works with historic objects and works of art. The continuously development of the theory, conservatory techniques and materials is accompanied by the dynamic development of a documentation and conservatory design techniques. The conservators have the chance to use more and more modern and universal devices to work. Among them there is the virtual reality technology. Digital camera and computer let us to portray ideally a space or expanse and give the chance to put accurate text or voice information within along with free access to the presentation. This article aim is to present the origin of this technology, its basic principle of work, essential devices, ways of use and application possibilities in terms of documentation and conservatory design. The full information about the virtual reality possibilities is broadened by the web sites addresses within the text.

8 Założenia pracy magisterskiej i wnioski z niej płynące autor pracy magisterskiej miał okazję wielokrotnie potwierdzić w praktyce. Od ponad pięciu lat technologię wirtualnej rzeczywistości budowanej na podstawie panoram sferycznych wykorzystuje codziennej w pracy konserwatora dzieł sztuki - od etapu przygotowywania do prac i prowadzenia badań przy obiekcie do dokumentacji konserwatorskiej. Panoramy sferyczne z powodzeniem wykorzystuje w tworzeniu wirtualnych spacerów po zabytkowych miejscach, po miastach, do budowania wirtualnych przewodników, publikacji multimedialny przybliżających różne zabytkowe miejsca. 


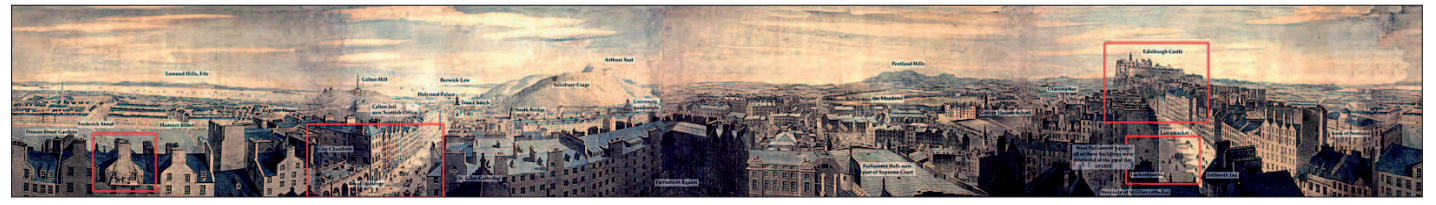

Fot. 1. Panorama Edynburga autorstwa Roberta Barkera. Zdjęcie za www.edvec.ed.ac.uk

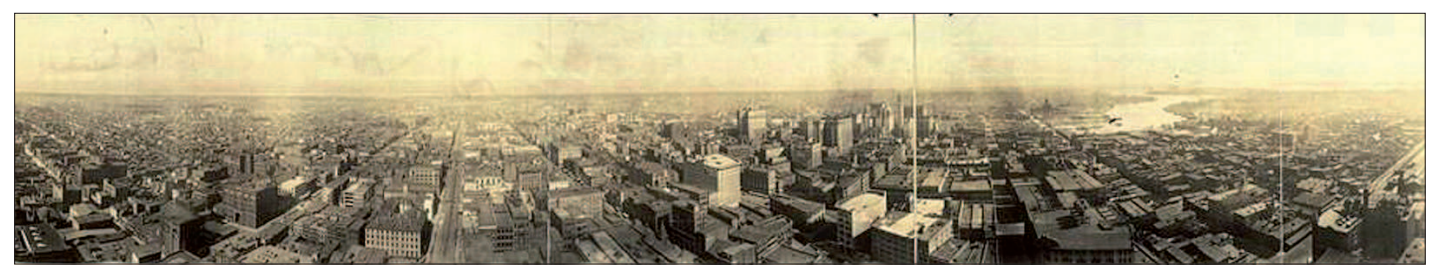

Fot. 2. Panorama miasta Baltimore z 1904 roku. Zdjęcie wykonano aparatem „Circut” firmy Kodak. Zdjęcie za www.hellobaltimore.com/Photos_Panoramic.Cfm
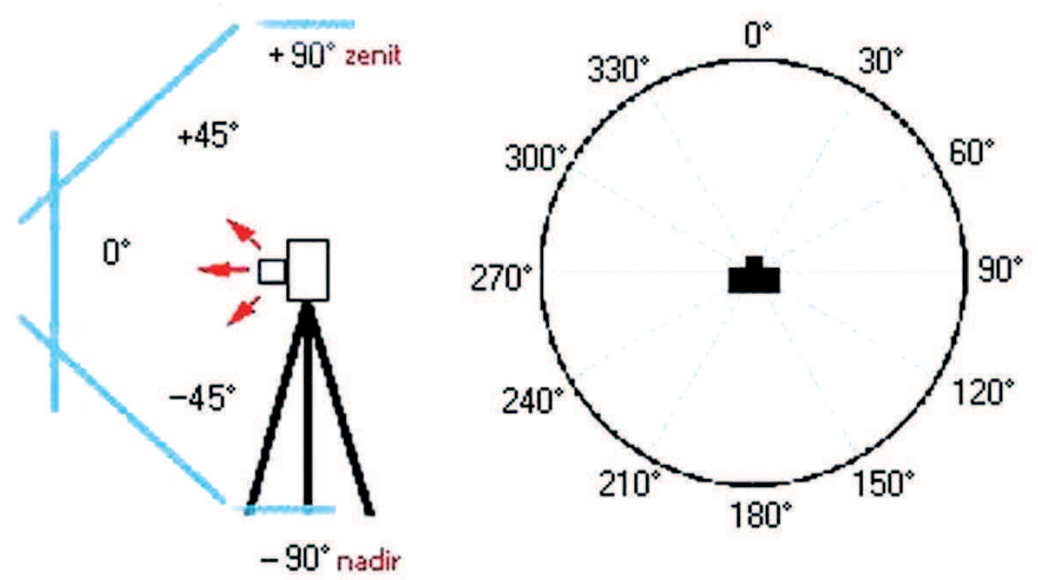

Rys. 1. Schemat ustawienia aparatu w trakcie wykonywania zdjęć do panoramy sferycznej 


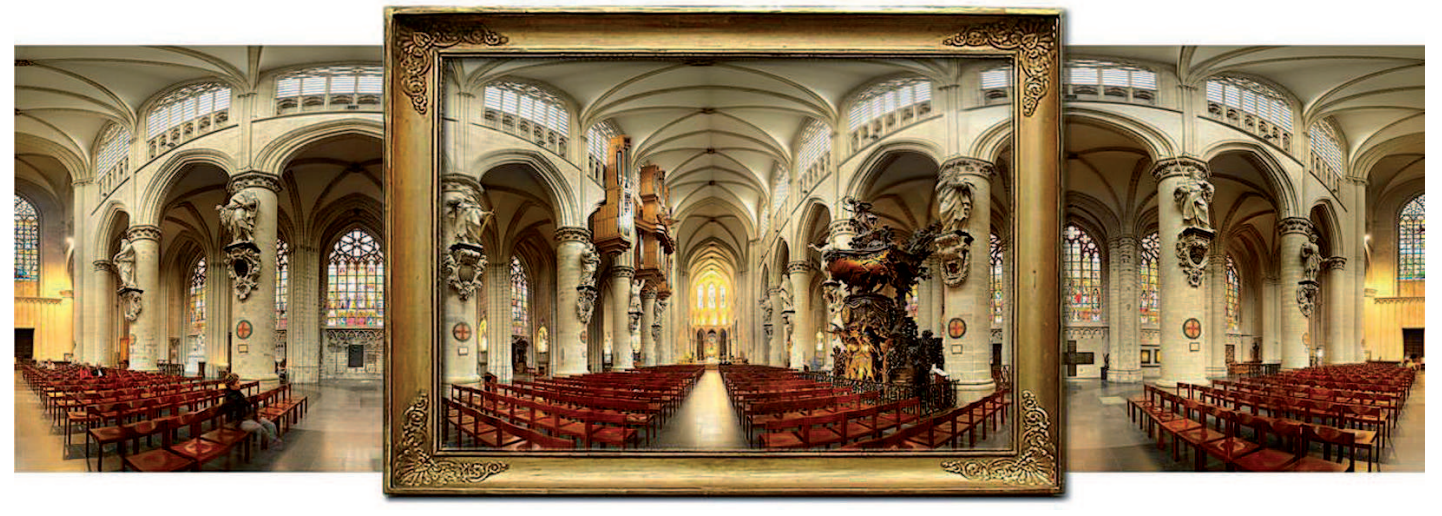

Fot. 3. Tradycyjna forma dokumentacji uzupełniona fotografiami i rysunkami, niedostatecznie pokazuje przestrzeń, $w$ jakiej funkcjonuje zabytek i relacje $z$ otoczeniem jakim podlega. Wirtualne, fotorealistyczne $\mathrm{i}$ interaktywne odwzorowanie całego wnętrza obiektu, „wykracza” więc poza ramy zwykłej fotografii i tradycyjnych metod dokumentowania

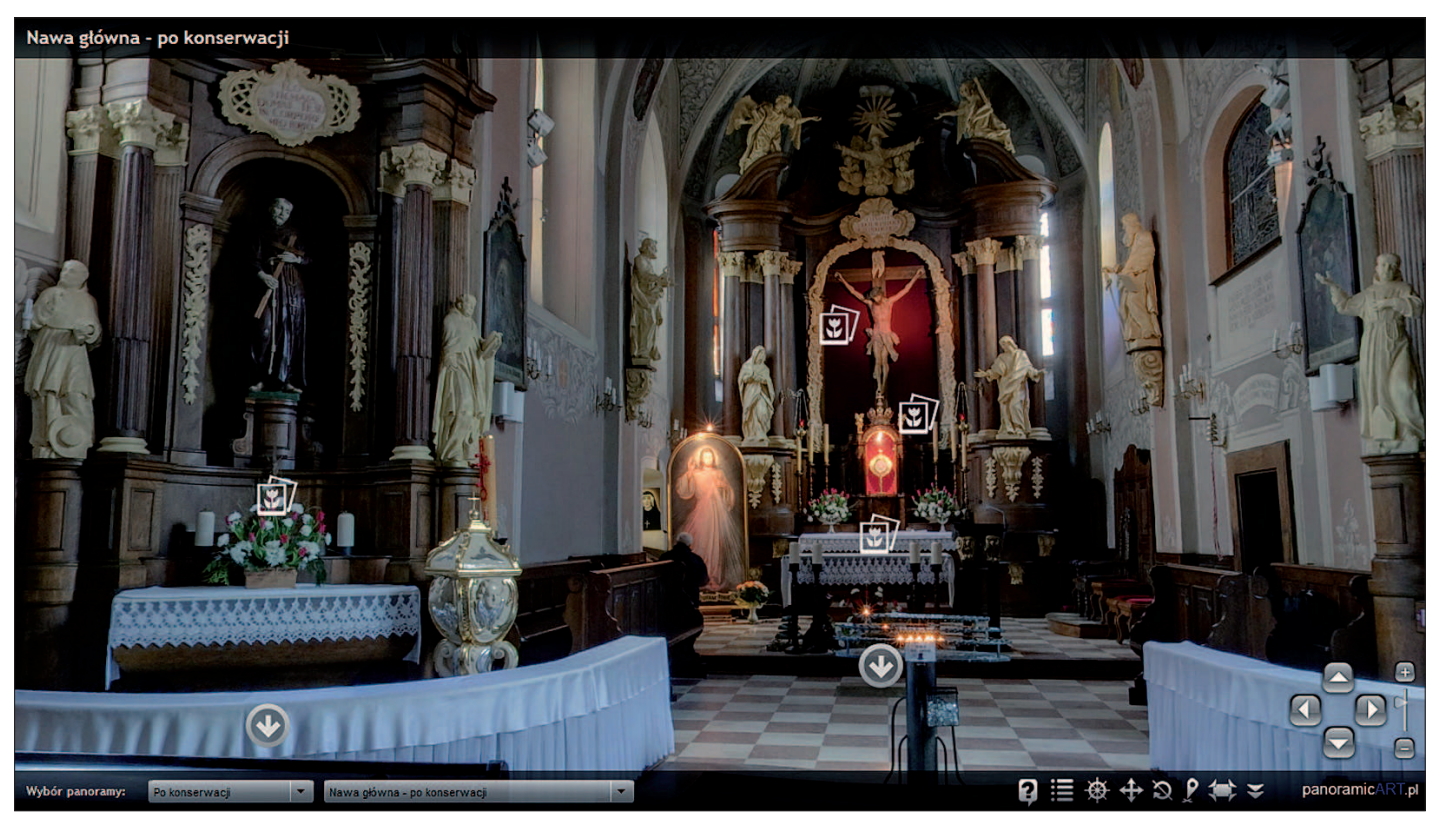

Fot. 4. Fragment dokumentacji konserwatorskiej prac w kościele św. Ap. Piotra i Pawła w Toruniu - Podgórz dostępny pod adresem panoramicart.home.pl/spacery/podgorz/ 


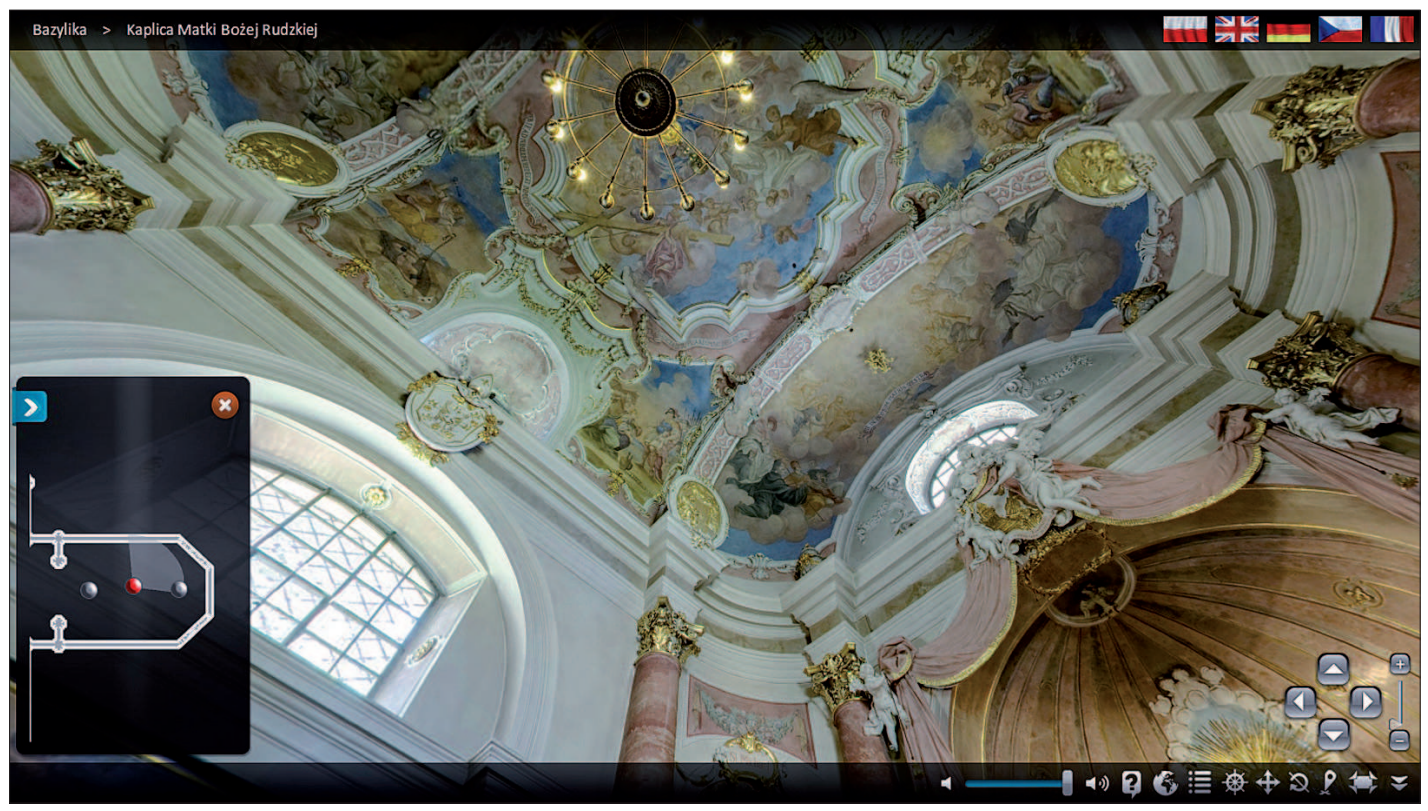

Fot. 5. Fotografia fragmentu wizualizacji pocysterskiego opactwa w Rudach Raciborskich http://panoramicart.home.pl/rudycd/

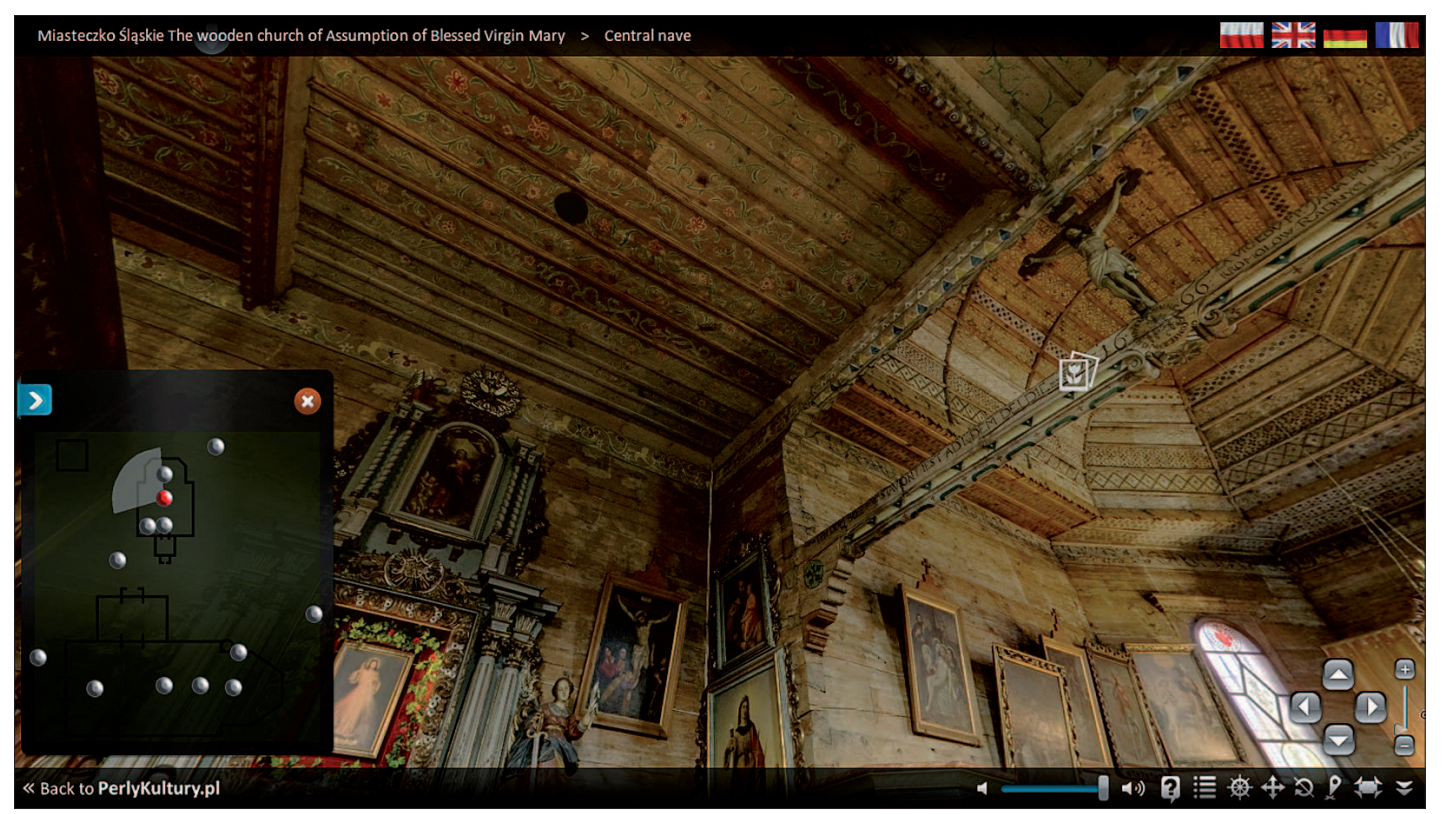

Fot. 6. Fotografia fragmentu prezentacji kościoła w Miasteczku Śląskim - część projektu wizualizacji kościołów diecezji gliwickiej http://panoramicart.home.pl/gliwice/ 


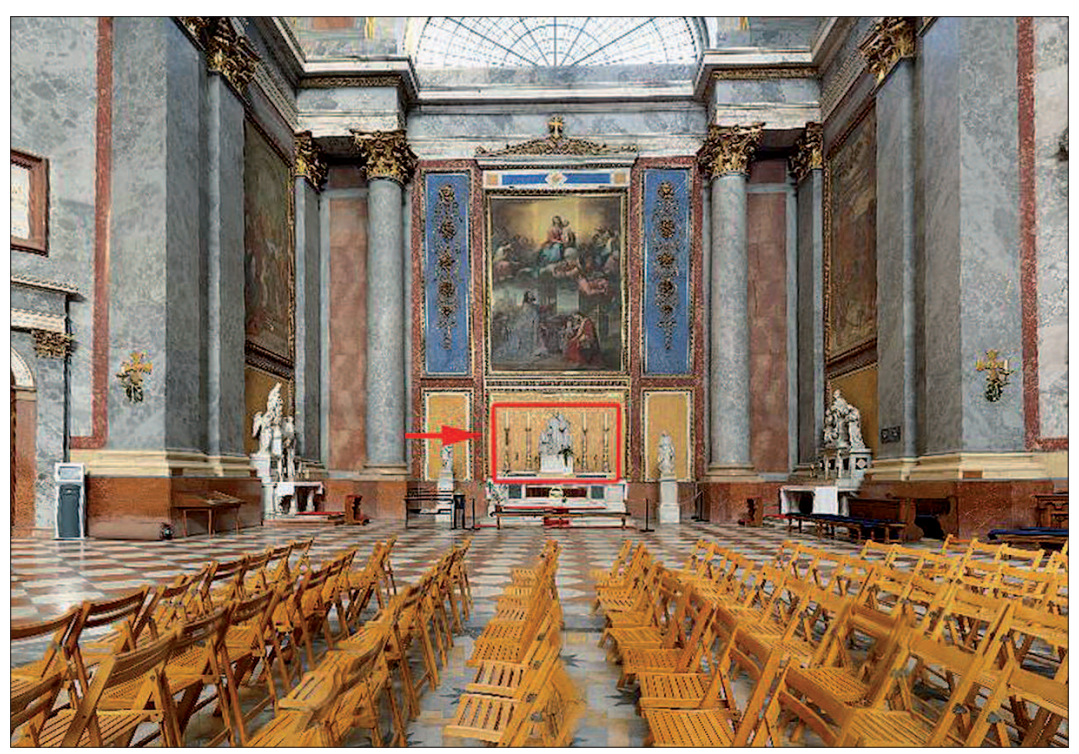

Fot. 7. Zdjęcie fragmentu panoramy wnętrza Bazyliki w Esztergomie (Węgry). Pojedyncza fotografia wchodzące w skład całości ma $2560 \times 1920$ pikseli, 72 dpi rozdzielczości i $90.3 \times 67.7 \mathrm{~cm}$ rozmiaru po jego wydrukowaniu w pełnej rozdzielczości. Umożliwia to wykonywanie znacznych zbliżeń w panoramie. Czerwona ramką oznaczono miejsce, w którym wykonano maksymalne zbliżenie (widoczne na następnym zdjęciu). Miejsce, z którego wykonywano ujęcia do panoramy, znajduje się prawie 20 metrów od zaznaczonego na powyższym zdjęciu ołtarza

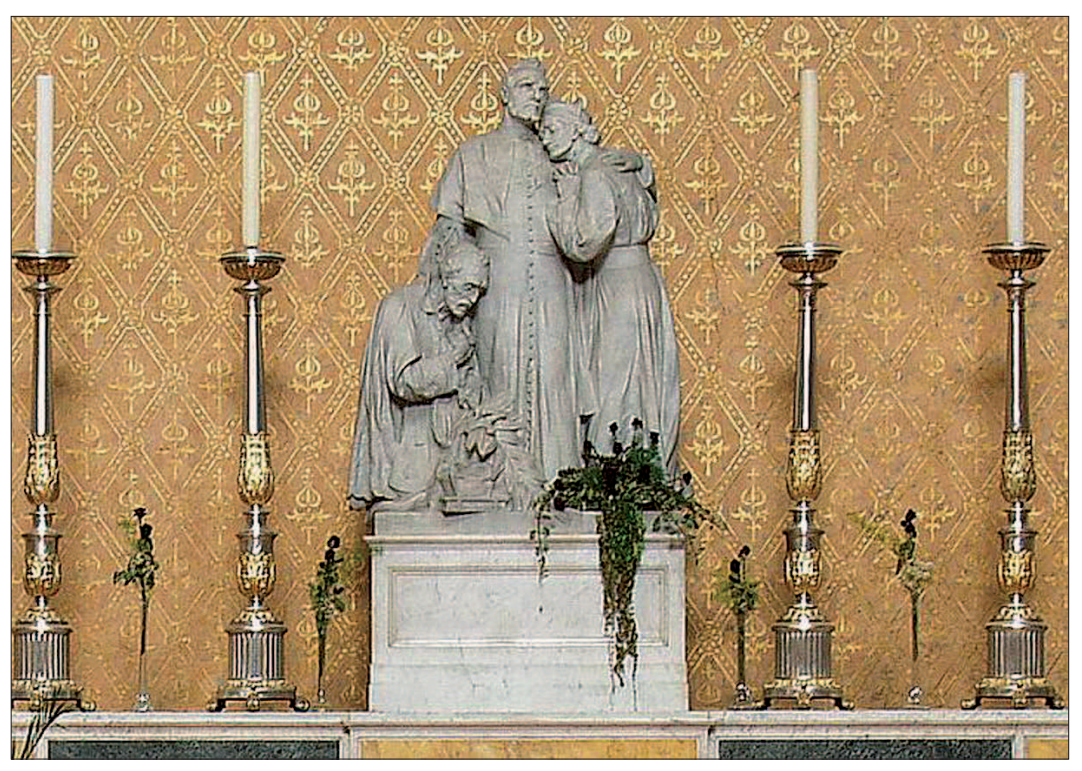

Fot. 8. Zdjęcie zbliżenia fragmentu panoramy (miejsce zaznaczone na poprzedniej ilustracji czerwoną ramka) 